\title{
Genetic influence of dopamine receptor, dopamine transporter, and nicotine metabolism on smoking cessation and nicotine dependence in a Japanese population
}

Masanori Ohmoto*, Tatsuo Takahashi, Yoko Kubota, Shinjiro Kobayashi and Yasuhide Mitsumoto

\begin{abstract}
Background: This study investigated whether polymorphisms of the ankyrin repeat and kinase domain containing 1 gene (ANKK1), which is adjacent to the dopamine D2 receptor gene (DRD2), and the dopamine transporter (SLC6A3) and cytochrome P450 2A6 (CYP2A6) genes influence smoking cessation and nicotine dependence in a Japanese population. In 96 current and former smokers, genotyping frequencies for the ANKK1/DRD2 TaqIA, SLC6A3 VNTR, and CYP2A6 polymorphisms were subjected to chi-square analysis, and regression analyses were used to determine the association of the genotypes of current smokers with a Heavy Smoking Index, in addition to evaluating the effect of the subjects' smoking history on the association.
\end{abstract}

Results: Genotyping results suggested that nicotine dependence among current smokers homozygous for the SLC6A3 10r allele was lower than that of smokers carrying the minor alleles, and that the CYP2A6 polymorphism might mediate this association. Furthermore, the age at which current smokers began smoking might moderate the association between their genetic polymorphisms and nicotine dependence.

Conclusions: This study provides preliminary findings on the influence of genetic variants on the smoking phenotypes in a Japanese population.

Keywords: ANKK1/DRD2 TaqIA polymorphism, CYP2A6*4 polymorphism, Nicotine dependence SLC6A3 VNTR polymorphism, Smoking cessation

\section{Background}

Nicotine activates the mesolimbic dopaminergic system and mediates positive reinforcing reward effects, primarily by releasing dopamine in the nucleus accumbens [1]. Although smoking behaviour is affected by a combination of genetic and environmental factors, genetic factors are known to play a key role in some aspects of smoking behaviour [2]. The association of specific genetic variants with the molecular mechanisms underlying the behavioural phenotypes of nicotine addiction has been investigated extensively, with a focus on dopaminergic transmissions. The TaqIA polymorphism (rs1800497) of the ankyrin repeat and kinase domain containing 1 gene

\footnotetext{
* Correspondence: m-ohmoto@hokuriku-u.ac.jp

Faculty of Pharmaceutical Sciences, Hokuriku University, Ho-3 Kanagawa-machi, Kanazawa 920-1181, Japan
}

(ANKK1) [3]-adjacent to the dopamine D2 receptor gene (DRD2) - is known to be associated with smoking behaviour. Several surveys $[4,5]$, predominantly with Caucasian subjects, have suggested that the A1 allele of this polymorphism increases the risk of smoking, whereas studies with Japanese subjects showed an association between the A2/A2 genotype and smoking risk [6,7]. We previously reviewed the effect of $A N K K 1 / D R D 2$ polymorphisms on smoking behaviour by considering the influence of ethnicity [8]. Our meta-analysis revealed a significant effect of $A N K K 1 / D R D 2$ polymorphisms on smoking cessation, which suggested that Caucasians carrying the A1 allele of the Taq1A polymorphism have a lower probability of smoking cessation than Asians do. It has been reported that the frequency of the A1 allele was higher in Americans (53-75\%) than in Asians (11-58\%) [9]. These significant 
ethnic differences in allele and genotype frequencies may be responsible for the inconsistent findings in previous studies on the role of the Taq1A ANKK1/DRD2 polymorphism in the smoking behaviour of Caucasians and Asians.

The dopamine transporter (SLC6A3) terminates synaptic transmission by the rapid and specific reuptake of dopamine in the synaptic clefts. Lerman et al. [10] investigated the association of smoking risk with the variable number of tandem repeat (VNTR) polymorphisms (rs28363170) in SLC6A3, in combination with the TaqIA polymorphism, and found polymorphism-polymorphism interaction, in which individuals with the SCL6A3 VNTR genotype that includes the 9-repeat (9r) allele were significantly less likely to be smokers, particularly if they also carried the TaqIA A2 allele. Sabol et al. [11] also demonstrated the significant effect of SLC6A3 9r genotypes on smoking cessation. However, other reports [12-14] did not replicate the initial positive results $[10,11]$. In studies of association between variant alleles of $A N K K 1 / D R D 2$ and $S L C 6 A 3$ and smoking, it has been suggested that the presence of the ANKK1/ DRD2 TaqIA A1 allele along with the SLC6A3 9r allele increases cigarette craving that is induced by a stressor $[15,16]$ and smoking reward and reinforcement by inducing a negative mood [17]. Furthermore, several reports $[10,14,18]$ have suggested that compared to non-carriers, carriers of $S L C 6 A 39 \mathrm{r}$ allele have a lower risk of starting to smoke early.

The genetic effect of the pharmacokinetics of nicotine on the association between alterations in synaptic dopamine levels and smoking phenotypes has not been well documented to data. Nicotine in the blood is metabolised into cotinine mainly by cytochrome P450 (CYP) 2A6. One of the functional polymorphisms of CYP2A6, the " 4 allele, is a particularly important polymorphic variant, with a gene deletion that is common in Asian populations [19]. It accounts for the majority of individuals with poor metabolism. Minematsu et al. [20] have reported that carriers of the "4 allele among Japanese smokers are more likely to be light rather than heavy smokers. Kubota et al. [21] also demonstrated that CYP2A6 genotypes including the "4 allele are associated with nicotine dependence and withdrawal symptoms upon smoking cessation. These reports have suggested that smoking-related phenotypes may be influenced by altering the nicotine concentration in the brain as a sequel to reduced nicotine metabolism. We hypothesized that the association between the ANKK1/DRD2 and SLC6A3 polymorphisms and smoking-related phenotypes might be influenced by variants in CYP2A6.

In light of the lack of research in polymorphism-polymorphism interactions in the Japanese population, we here investigated whether the combined polymorphic variants of SLC6A3 and ANKK1/DRD2, in the context of CYP2A6*4. genotypes, are associated with smoking-related phenotypes in a Japanese population, focussing on smoking cessation and nicotine dependence. Previous genetic association studies of these polymorphisms with smoking cessation and nicotine dependence are described briefly in Table 1. The present study also examined the effect of smoking history (age at which the participant began smoking and duration of smoking) on the association between SLC6A3, ANKK1/DRD2, and CYP2A6 polymorphisms and nicotine dependence.

\section{Results}

The allele and genotype frequencies for the $S L C 6 A 3$, $A N K K 1 / D R D 2$, and CYP2A6 polymorphisms in relation to smoking status for the 75 current and 21 former smokers are shown in Table 2. The distributions of the SLC6A3 VNTR and ANKK1/DRD2 TaqIA genotypes in current smokers, former smokers, and all participants did not deviate from Hardy-Weinberg equilibrium (HWE) to any appreciable extent, as determined by chi-squared tests. The allele frequencies of the SLC6A3 VNTR, ANKK1/DRD2 TaqIA, and CYP2A6*4 polymorphisms in all participants were similar to those from previous studies in Japanese populations $[6,7,33,34]$. Although the distribution of CYP2A6"4 genotypes in former smokers and all participants were different, the allele frequency of $C Y P 2 A 6^{*} 4$ in all participants were similar to those from a previous study [20].

The sex ratio and mean and standard deviation for age and smoking history of the participants, categorized by smoking status for each genotype of the SLC6A3, ANKK1/ $D R D 2$, and CYP2A6 polymorphisms, are shown in Table 3. There was no significant difference in age and smoking histories of participants among genotypes.

The gender ratio of the study population was skewed (see Table 2). Therefore, we performed analyses for the cohort as a whole $(n=96)$ as well as for the male subgroup only $(\mathrm{n}=88)$. As shown in Table 4 , subgrouping did not have an effect on detecting associations between the overall genotype frequencies and smoking status.

To assess whether the genotypes were associated with the Heavy Smoking Index (HSI) [35], as a measure of the degree of nicotine dependence, the HSI scores for current smokers were compared for each genotype, both in the whole cohort and in males only (Table 5). There was a significant association between the SLC6A3 VNTR polymorphisms and the HSI score, whereas no associations were found between the ANKK1/DRD2 TaqIA and CYP2A6 genotypes and the HSI score. The number of smokers with the $C Y P 2 A 6 * 1 / * 1$ genotype showing an HSI high-score was two-fold higher than that of smokers carrying the "4 allele.

Moreover, we evaluated the effect of the ANKK1/DRD2 and CYP2A6 genotypes on the association between the SLC6A3 VNTR polymorphism and the HSI score (Table 6). Regression analyses showed that the HSI score correlated better with the SLC6A3 VNTR and CYP2A6 genotypes 
Table 1 Association between smoking behaviour and nicotine dependence and ANKK1/DRD2 TaqIA, SLC6A3 VNTR, and CYP2A6 polymorphisms

\begin{tabular}{|c|c|c|}
\hline Study & Ethnicity & Samples \\
\hline \multicolumn{3}{|c|}{ ANKK1/DRD2 TaqIA polymorphism } \\
\hline Noble et al. (1994) & Caucasians & $\begin{array}{l}57 \text { current smokers, } 115 \text { former } \\
\text { smokers, and } 182 \text { non-smokers }\end{array}$ \\
\hline Comings et al. (1996) & Caucasians & 312 smokers \\
\hline Batra et al. (2000) & Caucasians & $\begin{array}{l}110 \text { heavy smokers and } 60 \text { light } \\
\text { smokers }\end{array}$ \\
\hline Bierut et al. (2000) & Caucasians & $\begin{array}{l}388 \text { habitual smokers and } 566 \\
\text { non-habitual smokers }\end{array}$ \\
\hline Yoshida et al. (2001) & Japanese & $\begin{array}{l}77 \text { current smokers, } 57 \text { former } \\
\text { smokers, and } 198 \text { never smokers }\end{array}$ \\
\hline Hamajima et al, (2002) & Japanese & $\begin{array}{l}226 \text { current smokers, } 133 \text { former } \\
\text { smokers, and } 434 \text { never smokers }\end{array}$ \\
\hline Johnstone et al. (2004) & Caucasians & 752 smokers \\
\hline
\end{tabular}

Association

Reference

Morton et al. (2006) Caucasians

Connor et al. (2007) Caucasians 84 smokers

\section{SLC6A3 VNTR polymorphism}

Lerman et al. (1999)

Caucasians (85\%) 289 smokers and 233 non-

African

Americans (15\%)

$\begin{array}{ll}\text { Sabol et al. (1999) } & \text { Caucasians } \\ \text { Jorm et al. (2000) } & \text { Caucasians } \\ \text { Vandenbergh et al. (2002) } & \text { Caucasians }\end{array}$

Perkins et al. (2008)

Caucasians

Laucht et al. (2008)

Caucasians

Sieminska et al. (2009)

Caucasians
1068 smokers, 213 non-smoking, and 1093 former smokers

smokers

72 smoker

220 ever smokers (adolescents)

Current smokers were more likely than former

164 current smokers and 111 211 former smokers, 198 current smokers, and 452 non-smokers 153 former smokers, 98 current smokers, 214 never smokers, and 114 non-smokers

The A1 allele scored higher on nicotine dependence

150 ever smokers and 158 never smokers
Smoking subjects showed a significantly higher prevalence of the A1 allele compared to controls. Both past and current smokers demonstrated a significantly higher prevalence of the A1 allele than non-smokers did.

There was a significant, inverse relationship between the prevalence of the $\mathrm{A} 1$ allele and the age of onset of smoking, and the maximum duration of time that smokers had been able to quit smoking on their own.

No significant findings

Smoking appeared to be associated with the A2/A2 genotype.

Males with the A2/A2 genotype had a higher risk of being current smokers.

At 1 week, the nicotine patch was more effective for smokers with the $A 1 / A 2$ or $A 1 / A 1$ genotypes than for those with the A2/A2 genotype; this was not the case at the 12-week flow up. smokers to possess the A1 allele.

Compared to carriers of the A2/A2 genotype, carriers of the $A 1 / A 1$ or $A 1 / A 2$ genotypes were characterised by higher levels of cigarette consumption.

Individuals with the $9 \mathrm{r}$ allele were significantly less likely to be smokers, particularly if they also carried the A2/A2 genotype. Smokers carrying the $9 r$ allele genotype were also significantly less likely to have started smoking before 16 years of age and had prior smoking histories, indicating a longer period of prior smoking cessation.

The $9 \mathrm{r}$ allele was associated with smoking cessation.

No associations were found with either smoking

initiation or smoking cessation.

Never smokers showed a higher prevalence of the 10 allele compared to current smokers. The frequency of the 10r allele in never-smokers (no cigarettes ever) was more than that in other smokers.

The increase in smoking amount owing to negative mood was associated with the A2/A2 allele and the $9 r$ allele. than their allelic counterparts. The intention to quit smoking was significantly lower in adolescents for the 10r/10r genotype.

The abstinence periods during quitting attempts of carriers of the A1 allele were longer than those of non-carriers. The odds ratio for heavy smoking was higher in carriers of the A1 or $9 r$ alleles compared to that in non-carriers. Compared to non-carriers, carriers of the $9 r$ allele had a lower risk to start smoking before the age of 20 years.
No significant findings 
Table 1 Association between smoking behaviour and nicotine dependence and ANKK1/DRD2 TaqIA, SLC6A3 VNTR, and CYP2A6 polymorphisms (Continued)

\begin{tabular}{|c|c|c|c|c|}
\hline \multicolumn{5}{|c|}{ CYP2A6 polymorphism (*4 allele) } \\
\hline Tan et al. (2001) & Chinese & $\begin{array}{l}174 \text { smokers and } 152 \text { non- } \\
\text { smokers }\end{array}$ & $\begin{array}{l}\text { The distribution of the CYP2A6 genotype frequencies } \\
\text { was not significantly different. }\end{array}$ & [28] \\
\hline Loriot et al. (2001) & Caucasians & $\begin{array}{l}185 \text { heavy smokers and } 203 \text { light } \\
\text { smokers }\end{array}$ & $\begin{array}{l}\text { No significant relationship between genetically } \\
\text { impaired nicotine metabolism and cigarette } \\
\text { consumption related and the presence of defective } \\
\text { CYP2A6 alleles (* } 2 \text { and }{ }^{*} 4 \text { alleles). }\end{array}$ & {$[29]$} \\
\hline Ando et al. ( 2003) & Japanese & $\begin{array}{l}57 \text { current smokers, } 44 \text { former } \\
\text { smokers, and } 139 \text { never smokers }\end{array}$ & $\begin{array}{l}\text { The proportion of never smokers among } \\
\text { heterozygous carriers of the }{ }^{*} 4 \text { allele was similar } \\
\text { among subjects with the }{ }^{*} 1 /^{*} 1 \text { genotype. CYP2A6 } \\
\text { genotypes did not correlate either with the number } \\
\text { of cigarettes smoked per day or with the age of } \\
\text { smoking commencement. }\end{array}$ & {$[30]$} \\
\hline Minematsu et al. (2003) & Japanese & $\begin{array}{l}92 \text { current smokers, } 111 \text { former } \\
\text { smokers, and } 123 \text { non-smoker }\end{array}$ & $\begin{array}{l}\text { The percentage of subjects with a CYP2A6del }\left({ }^{*} 4\right) \\
\text { allele was lower among heavy smokers than among } \\
\text { light smokers or non-smokers and was lower among } \\
\text { ex-smokers than among current smokers. }\end{array}$ & {$[20]$} \\
\hline Fujieda et al. (2004) & Japanese & $\begin{array}{l}1094 \text { patient (cancer) subjects } \\
\text { and } 611 \text { healthy subjects }\end{array}$ & $\begin{array}{l}\text { The amount of daily cigarette consumption in } \\
\text { subjects who harboured the CYP } 2 A 6^{*} 4 \text { allele was } \\
\text { significantly less than that in subjects carrying the } \\
{ }^{*} 1 /^{*} 1 \text { genotype. }\end{array}$ & [31] \\
\hline Kubota et al. (2006) & Japanese & 107 smokers & $\begin{array}{l}\text { CYP2A6 high-activity group }\left(C Y P 2 A 6^{*} 1 /{ }^{*} 1, * * 1 /{ }^{*} 4 \text {, etc.) }\right. \\
\text { smoked the first cigarette of the day earlier than the } \\
\text { low-activity group }\left(C Y P 2 A 6^{*} 4 /{ }^{*} 4\right) \text {, indicating more } \\
\text { marked nicotine dependence. Nicotine withdrawal } \\
\text { symptoms were more serious during smoking } \\
\text { cessation in the CYP2A6 high-activity group. }\end{array}$ & {$[21]$} \\
\hline Liu et al. (2011) & Chinese & $\begin{array}{l}970 \text { current smokers and } 358 \\
\text { former smokers }\end{array}$ & $\begin{array}{l}\text { Poor metabolizers reported smoking fewer cigarettes } \\
\text { per day, started smoking regularly at a later age, and } \\
\text { smoked for a shorter duration than did normal } \\
\text { metabolizers. However, poor metabolizers were less } \\
\text { likely to quit smoking than normal metabolizers were. }\end{array}$ & {$[32]$} \\
\hline
\end{tabular}

than with the SLC6A3 VNTR only in the total cohort (AIC value: 75.327). Regression analysis of the male subgroup only also showed a high correlation between the HSI score and the SLC6A3 VNTR and CYP2A6 genotypes, although this did not reach statistical significance (AIC value: 70.761; $\mathrm{P}=0.018$ ).

The proportion of HSI scores $\geq 4$ for individuals with the SLC6A3 10r/10r genotype was lower than that of individuals with a single or no copy of the 10r allele, suggesting that the CYP2A6 genotype might affect the relationship. We performed regression analyses to determine the effect of two variables in smoking histories on the association between nicotine dependence and genetic polymorphisms. As shown in Table 7, the HSI score was significantly correlated with the SLC6A3 VNTR and CYP2A6 genotypes when the age at which the participant began smoking was included as a variable in analysis of the whole cohort. Regression analysis of the male subgroup only (AIC value: 74.250), rather than that of the whole cohort (AIC value; 69.921), also showed a high correlation between the HSI score and a 3-variable combination (SLC6A3 genotypes, CYP2A6 genotypes, and age at which the participant began smoking), although this did not reach statistical significance $(\mathrm{P}=0.014)$.

\section{Discussion}

This study examined whether functional polymorphisms in SLC6A3, ANKK1/DRD2, and CYP2A6 affect smoking cessation and nicotine dependence in a Japanese population. We found that current smokers with the SLC6A3 10r/10r genotype were more likely to have low nicotine dependence, based on HSI analysis, although the genotypic differences between current and former smokers were not significant for any of the SLC6A3, ANKK1/ $D R D 2$, and $C Y P 2 A 6$ polymorphisms tested. Previous studies $[36,37]$ suggested that the $9 \mathrm{r}$ allele enhanced the expression of the SLC6A3 protein, resulting in reduced postsynaptic dopamine activity. The 10r allele has been implicated in reduced SLC6A3 protein expression; thus, it might decrease the extent of nicotine dependence, by increasing the total amount of dopamine that is released into the synaptic cleft, thereby providing a greater reward from the dopaminergic effects of nicotine. 
Table 2 Allele frequency profiles for SLC6A3, ANKK1/DRD2, and CYP2A6 polymorphism genotypes for current and former smokers

\begin{tabular}{|c|c|c|c|c|c|c|}
\hline \multirow[t]{2}{*}{ Allele/Genotype } & \multicolumn{2}{|l|}{$A I^{a}$} & \multicolumn{2}{|c|}{ Current smoker } & \multicolumn{2}{|c|}{ Former smoker } \\
\hline & Number & $\%$ & Number & $\%$ & Number & $\%$ \\
\hline \multicolumn{7}{|l|}{ SLC6A3 } \\
\hline $10 r$ & 172 & 89.6 & 136 & 90.7 & 36 & 85.7 \\
\hline $9 r$ & 9 & 4.7 & 7 & 4.7 & 2 & 4.8 \\
\hline $7 r$ & 8 & 4.2 & 6 & 4.0 & 2 & 4.8 \\
\hline $6 r$ & 3 & 1.6 & 1 & 0.7 & 2 & 4.8 \\
\hline 10r/10r & 77 & 80.2 & 61 & 81.3 & 16 & 76.2 \\
\hline $10 r / 9 r$ & 9 & 9.4 & 7 & 9.3 & 2 & 9.5 \\
\hline $10 r / 7 r$ & 6 & 6.3 & 6 & 8.0 & 0 & 0.0 \\
\hline $10 r / 6 r$ & 3 & 3.1 & 1 & 1.3 & 2 & 9.5 \\
\hline $7 r / 7 r$ & 1 & 1.0 & 0 & 0.0 & 1 & 4.8 \\
\hline HWE ${ }^{\mathrm{b}} P$-value & 0.96 & & 0.37 & & 0.31 & \\
\hline \multicolumn{7}{|l|}{ ANKK1/DRD2 } \\
\hline $\mathrm{A} 2$ & 112 & 58.3 & 91 & 60.7 & 21 & 50.0 \\
\hline A1 & 80 & 41.7 & 59 & 39.3 & 21 & 50.0 \\
\hline $\mathrm{A} 2 / \mathrm{A} 2$ & 33 & 34.4 & 27 & 36.0 & 6 & 28.6 \\
\hline $\mathrm{A} 2 / \mathrm{A} 1$ & 46 & 47.9 & 37 & 49.3 & 9 & 42.9 \\
\hline $\mathrm{A} 1 / \mathrm{A} 1$ & 17 & 17.7 & 11 & 14.7 & 6 & 28.6 \\
\hline HWE ${ }^{\mathrm{b}} P$-value & 0.89 & & 0.77 & & 0.51 & \\
\hline \multicolumn{7}{|l|}{ CYP2A6 } \\
\hline$*_{1}$ & 164 & 85.4 & 126 & 84.0 & 38 & 90.5 \\
\hline$* 4$ & 28 & 14.6 & 24 & 16.0 & 4 & 9.5 \\
\hline$*^{*} 1 /{ }^{*} 1$ & 73 & 76.0 & 55 & 73.3 & 18 & 85.7 \\
\hline${ }^{*} 1 /{ }^{*} 4$ & 18 & 18.8 & 16 & 21.3 & 2 & 9.5 \\
\hline$* 4 / * 4$ & 5 & 5.2 & 4 & 5.3 & 1 & 4.8 \\
\hline HWE ${ }^{b} P$-value & 0.02 & & 0.07 & & 0.04 & \\
\hline
\end{tabular}

${ }^{a}$ Number of alleles or genotypes for combined current and former smokers; and ${ }^{\mathrm{b}} \mathrm{Hardy}$-Weinberg equilibrium of genotype distributions of each polymorphism was tested for current smokers, former smokers, and the whole cohort.

Regarding the association between the SLC6A3 VNTR polymorphism and smoking cessation, initial studies $[10,11]$ and a meta-analysis [38] have suggested that individuals carrying the $9 \mathrm{r}$ allele, rather than the more common 10r allele, had a greater likelihood of smoking cessation. However, these results have not been replicated [12,13], and the meta-analysis did not include Asian populations. Further studies are therefore needed to clarify the effects of the $9 \mathrm{r}$ and 10r alleles on smoking cessation.

As for the effect of the SLC6A3 VNTR polymorphism on nicotine dependence, O'Gara et al. [39] reported a lack of association between the SLC6A3 VNTR polymorphism and the HSI score for smokers attempting to quit by using either nicotine replacement therapy or bupropion. Nicotine dependence has been estimated using the Fagerstrom Test for Nicotine Dependence (FTND) [40]. De Leon et al. [41] suggested that use of the FTND in epidemiological surveys may lead to inaccurate conclusions, and that nicotine dependence should be measured only by the number of cigarettes smoked per day or the time to the first cigarette of the day. In addition, defining heavy smoking as more than 30 cigarettes per day would lead to underdiagnosis of individuals with high nicotine dependence. We therefore assessed nicotine dependence using the more accurate HSI and obtained significant results that suggested that low nicotine dependence was related to the 10r/10r genotype. Kozlowski et al. [42] suggested that their scales of nicotine dependence should be limited to predicting how heavily a person smokes rather than predicting the chances of quitting smoking. Thus, the differing relationships between smoking cessation and nicotine dependence with genetic influences are probably not contradictory.

Our finding suggests that variants in CYP2A6 might affect the association of the VNTR SLC6A3 polymorphism with nicotine dependence, although no significant association was found between the CYP2A6 polymorphism and nicotine dependence. Because heavy smoking (high HSI score) was more frequent among individuals carrying the CYP2A6 "1 allele, these results might indicate an association between the CYP2A6 polymorphism and high nicotine dependence. Kubota et al. [21] had previously demonstrated that the HSI score was significantly higher in the CYP2A6 high-activity group carrying the "1 allele than in the low-activity group (homozygous for minor alleles, including *4). We found that current smokers with the 10r/10r genotype were more likely to have low nicotine dependence based on HSI analysis, although the genotypic differences between current and former smokers were not significant for any of the $S L C 6 A 3$, $A N K K 1 / D R D 2$, and CYP2A6 polymorphisms.

Chronic exposure to a low concentration of nicotine is considered to desensitize nicotinic acetylcholine receptors significantly, which then turn over more slowly [43]. Individuals with high CYP2A6 activity may be able to maintain a low level of nicotine in the brain, which might influence dopaminergic activity via the nicotinic receptor, resulting in a craving for a short term, large dose of nicotine.

We speculate that the 10r/10r genotype might decrease expression of the SLC6A3 protein, which might result in a chronically high level of extracellular dopamine, protecting them from a craving for heavier smoking. The existence of a null allele in CYP2A6 affects the related enzyme activity. It is possible that individuals carrying the " 1 allele could inactivate nicotinic receptors constitutively by the high activity of CYP2A6, decreasing dopamine release into the synaptic clefts. CYP2A6 polymorphisms might mediate the association between the 10r/10r genotype and low nicotine dependence. 
Table 3 Profiles of participants were categorized by smoking status for SLC6A3, ANKK1/DRD2, and CYP2A6 polymorphism genotypes

\begin{tabular}{|c|c|c|c|c|c|}
\hline \multicolumn{6}{|l|}{ (A) Current smoker } \\
\hline \multirow[t]{2}{*}{ Genotypes } & \multicolumn{2}{|c|}{ Number } & \multirow[t]{2}{*}{ Age } & \multirow{2}{*}{$\begin{array}{l}\text { Age at which } \\
\text { participant began smoking }\end{array}$} & \multirow{2}{*}{$\begin{array}{l}\text { Duration of } \\
\text { smoking }\end{array}$} \\
\hline & Male & Female & & & \\
\hline SLC6A3 10r/10r & 57 & 4 & $31.51 \pm 11.72$ & $19.33 \pm 2.01$ & $11.82 \pm 11.12$ \\
\hline \multirow[t]{2}{*}{ 10r/\# or \#/\# } & 12 & 2 & $36.93 \pm 13.36$ & $19.36 \pm 1.84$ & $16.43 \pm 13.12$ \\
\hline & & $P$-value & 0.119 & 0.855 & 0.361 \\
\hline ANKK1/DRD2 A2/A2 & 25 & 2 & $34.05 \pm 13.89$ & $19.67 \pm 2.15$ & $13.98 \pm 13.99$ \\
\hline \multirow[t]{2}{*}{$\mathrm{A} 2 / \mathrm{A} 1$ or $\mathrm{A} 1 / \mathrm{A} 1$} & 44 & 4 & $31.65 \pm 11.09$ & $19.15 \pm 1.87$ & $11.95 \pm 10.05$ \\
\hline & & $P$-value & 0.435 & 0.523 & 0.965 \\
\hline CYP2A6 $* 1 /{ }^{*} 1$ & 50 & 5 & $32.58 \pm 11.79$ & $19.27 \pm 2.09$ & $13.05 \pm 11.90$ \\
\hline \multirow[t]{2}{*}{$* 1 / * 4$ or * $4 / * 4$} & 20 & 1 & $31.90 \pm 13.16$ & $19.14 \pm 2.31$ & $11.24 \pm 10.73$ \\
\hline & & $P$-value & 0.716 & 0.846 & 0.654 \\
\hline \multicolumn{6}{|l|}{ (B) Former smoker } \\
\hline \multirow[t]{2}{*}{ Genotypes } & \multicolumn{2}{|c|}{ Number } & \multirow[t]{2}{*}{ Age } & & \\
\hline & Male & Female & & & \\
\hline SLC6A3 10r/10r & 15 & 1 & $48.69 \pm 10.98$ & & \\
\hline \multirow[t]{2}{*}{ 10r/\# or \#/\# } & 4 & 1 & $51.2 \pm 6.98$ & & \\
\hline & & $P$-value & 0.901 & & \\
\hline ANKK1/DRD2 A2/A2 & 6 & 0 & $50.667 \pm 8.824$ & & \\
\hline \multirow[t]{2}{*}{$\mathrm{A} 2 / \mathrm{A} 1$ or $\mathrm{A} 1 / \mathrm{A} 1$} & 13 & 2 & $48.733 \pm 10.760$ & & \\
\hline & & $P$-value & 0.697 & & \\
\hline CYP2A6 *1/*1 & 16 & 2 & $49.44 \pm 10.56$ & & \\
\hline \multirow[t]{2}{*}{$*^{*} 1 / *^{*}$ or $* 4 /{ }^{*} 4$} & 3 & 0 & $48.33 \pm 8.02$ & & \\
\hline & & $P$-value & 0.840 & & \\
\hline
\end{tabular}

\#DAT alleles with less than 10 repeats. $P$-value; the Mann-Whitney $\mathrm{U}$ test was conducted for participant age and smoking history of each genotype.

We also determined the effect of smoking history on the relationship between nicotine dependence and genetic polymorphisms. Our results suggested that the age at which current smokers began smoking might moderate the effect of SLC6A3 and CYP2A6 polymorphisms on nicotine dependence. Individuals with the $S L C 6 A 39$ r genotypes were significantly less likely to have started smoking earlier $[10,14]$. A previous survey conducted on currently smoking adolescent subjects demonstrated that individuals

Table 4 Odds ratios for the SLC6A3, ANKK1/DRD2, and CYP2A6 genotypes in current and former smokers

\begin{tabular}{llll}
\hline Genotype & Number & OR $(\mathbf{9 5 \%} \mathbf{C l})$ & $\boldsymbol{P}$ value \\
\hline SLC6A3 10r/10r & $61 / 16,57 / 15$ & $1.362(0.427-4.344)$, & 0.831, \\
10r/\# or \#/\# & $14 / 5,12 / 4$ & $1.27(0.357-4.495)$ & 0.975 \\
ANKK1/DRD2 A2/A2 & $27 / 6,25 / 6$ & $1.406(0.488-4.050)$, & 0.709, \\
A2/A1 or A1/A1 & $48 / 15,44 / 13$ & $1.231(0.416-3.642)$ & 0.917 \\
CYP2A6 *1/*1 & $55 / 18,49 / 20$ & $0.458(0.122-1.725), 0.459$ & 0.376, \\
$* 1 / * 4$ or *4/*4 & 20/3, 20/3 & $(0.120-1.751)$ & 0.387 \\
\hline
\end{tabular}

Each analysis was performed for the whole cohort (the left side) and the male subgroup only (the right side). \#DAT alleles with less than 10 repeats. Number, current smokers per former smokers; OR, odds ratio; and $\mathrm{Cl}$, confidence interval.
Table 5 Effect of genetic polymorphisms and smoking histories of participants on nicotine dependence in current smokers: Odds ratios for the SLC6A3, ANKK1/DRD2, and CYP2A6 genotypes in current smokers with nicotine dependence

\begin{tabular}{llll}
\hline Genotype & Number & OR $(95 \% \mathrm{Cl})$ & $\boldsymbol{P}$ value \\
\hline SLC6A3 10r/10r & $9 / 52,8 / 49$ & $0.130(0.036-0.464)$, & $0.002,0.003$ \\
10r/\# or \#/\# & $8 / 6,7 / 5$ & $0.117(0.030-0.459)$ & \\
ANKK1/DRD2 A2/A2 & $4 / 23,4 / 21$ & $0.468(0.136-1.615)$, & $0.352,0.570$ \\
\hline A2/A1 or A1/A1 & $13 / 35,11 / 33$ & $0.571(0.161-2.032)$ & \\
CYP2A6 ${ }^{*} 1 /{ }^{* 1}$ & $15 / 39,13 / 36$ & $3.654(0.757-17.634)$, & $0.165,0.235$ \\
${ }^{*} 1 /{ }^{*}$ or ${ }^{*} 4 / 4$ & $2 / 19,2 / 18$ & $3.250(0.661-15.979)$ &
\end{tabular}

Each analysis was performed for the whole cohort (the left side) and the male subgroup only (the right side). \#DAT alleles with less than 10 repeats. Number, numbers of subjects respectively indicated with high $(\geq 4)$ per low scores $(<4)$ of HSI, Heavy Smoking Index (summary score of the number of cigarettes smoked per day and the time to the first cigarette of the day extracted from the Fagerstrom Test for Nicotine Dependence) in current smokers; $\mathrm{OR}$, odds ratio; $\mathrm{Cl}$, confidence interval. 
Table 6 Effect of genetic polymorphisms and smoking histories of participants on nicotine dependence in current smokers: Regression analysis of the effect of combinations of genetic polymorphisms on nicotine dependence

\begin{tabular}{llll}
\hline Genes & $\mathbf{R}^{2}$ & AIC & $P$-value \\
\hline SLC6A3 & $0.054,0.048$ & $77.940,72.719$ & $0.025,0.040$ \\
SLC6A3 + ANKK1/DRD2 & $0.057,0.260$ & $78.660,74.262$ & $0.045,0.098$ \\
SLC6A3 + CYP2A6 & $0.098,0.087$ & $75.327^{*}, 70.761$ & $0.009,0.018$ \\
\hline
\end{tabular}

Each analysis was performed for the whole cohort (the left side) and the male subgroup only (the right side). Forward-selection regression began with the effect of the SLC6A3 polymorphism alone. Variables were added one at a time to the model until no remaining variable produced a significant result. SLC6A3: input 1 or 0 for the 10r/10r or other genotype, respectively; ANKK1/DRD2: input 1 for the A2/A2 genotype, 0 for the A1/A2 or A1/A1 genotypes; CYP2A6: input 1 for the ${ }^{*} 1 /{ }^{*} 1$ genotype, 0 for genotypes including the ${ }^{*} 4$ allele. $R^{2}$, squared multiple correlation coefficient adjusted for degrees of freedom; AIC, Akaike's information criterion. ${ }^{*}$ The appropriate model was selected on the basis of minimising AIC.

homozygous for the 10r allele had a significantly lower intention to quit smoking than their allelic counterparts [18] did. Our findings suggested that the age of smoking initiation might be associated with nicotine dependence, under the influence of the SLC6A3 VNTR polymorphism.

Our results showing an association between the ANKK1/ DRD2 TaqIA polymorphism and smoking status were not consistent with previous data on Japanese males [6,7]. Previous studies have suggested that the A2/A2 genotype increased the risk of being a current smoker among the Japanese population, whereas studies with Caucasian subjects suggested that the A1 allele was associated with susceptibility to smoking [4,5]. A previous meta-analysis [44] suggested a lack of association between the TaqIA polymorphism and smoking behaviour and found evidence of strong heterogeneity between studies. No association of the HSI score with TaqIA polymorphism was observed in this study. The TaqIA polymorphism may thus not have a simple association with smoking status and nicotine dependence.

Table 7 Effect of genetic polymorphisms and smoking histories of participants on nicotine dependence in current smokers: Regression analysis of the effect of smoking history on the association between genetic polymorphisms and nicotine dependence

\begin{tabular}{llll}
\hline Variable & $\mathbf{R}^{2}$ & AIC & $P$-value \\
\hline SLC6A3 + CYP2A6 & $0.098,0.087$ & $75.327,70.761$ & $0.009,0.018$ \\
SLC6A3 + CYP2A6 + A & $0.133,0.110$ & $74.250^{*}, 69.921$ & $0.007,0.014$ \\
SLC6A3 + CYP2A6 +D & $0.127,0.101$ & $74.808,70.615$ & $0.009,0.019$ \\
\hline
\end{tabular}

Each analysis was performed for the whole cohort (the left side) and the male subgroup only (the right side). Forward-selection regression was conducted with the effect of the SLC6A3 and CYP2A6 genes. Variables were added one at a time to the model until no remaining variable produced a significant result. A: age at which participant began smoking, $D$; duration of smoking. $R^{2}$, squared multiple correlation coefficient adjusted for degrees of freedom; AIC, Akaike's information criterion. *The appropriate model was selected on the basis of minimising AIC.
The TaqIA polymorphism was originally thought to be located in the $3^{\prime}$-untranslated region of DRD2, but recent evidence suggests that it lies within the region encoding the putative substrate-binding domain of ANKK1 [3]. The role of ANKK1 has not been fully elucidated, but the TaqIA polymorphism may be in linkage disequilibrium, in an ethnic group-specific manner, with unidentified polymorphisms in a neighbouring gene that functions in the signal transduction pathway and that has a stronger influence on dopamine reward processing.

There are several limitations to this study. First, the small sample size must be noted. The inconclusive results may have been the result of insufficient statistical power to detect associations with small effects. Because of the small sample size, we did not standardize the environmental factors in detail, which may have caused selection and confounding biases. Second, the accuracy of the selfreported questionnaire was not validated, and the screening test for nicotine dependence did not type participants into subtypes. Third, the molecular mechanisms underlying the associations between the SLC6A3 VNTR and ANKK1/DRD2 TaqIA polymorphisms and smoking behaviour are uncertain and require clarification.

The degree to which our results can be generalized is not clear, but the present study provides a preliminary report in a Japanese population, and suggests that genetic studies on smoking should be based on ethnicity. Future large analyses on the multiple influences of polymorphism-polymorphism interactions, i.e. among the functional genetic polymorphisms of SLC6A3, ANKK1/ $D R D 2, C Y P 2 A 6$, and other related molecules, on smoking behaviour and nicotine dependence in different ethnic groups could address the problem of small sample size and lead to conclusions that are more reliable.

\section{Conclusions}

The genotyping results suggest that nicotine dependence in current smokers who are homozygous for the SLC6A3 10r allele was lower than that in individuals carrying the minor alleles, and that CYP2A6 polymorphisms might mediate this association. Furthermore, the age at which smokers begin smoking might moderate the association between their genetic polymorphisms and nicotine dependence. This study provides preliminary results regarding the effect of the SLC6A3 VNTR, ANKK1/DRD2 TaqIA, and CYP2A6*4 polymorphisms on smoking cessation and nicotine dependence in a Japanese population.

\section{Methods}

\section{Participants}

Ninety-six Japanese ever-smokers were recruited from among the students, staff, and their siblings at Hokuriku University. The institutional review committee of Hokuriku 
University approved this study, and all participants gave their informed consent.

Participants were categorized as current smokers $(\mathrm{n}=75,69$ males, 6 females, mean age: $32.52 \pm 12.13$ years) or former smokers ( $\mathrm{n}=21,19$ males, 2 females, mean age: $49.29 \pm 10.07$ years) if they had quit at least 1 year prior to the interview. The current smokers completed the FTND [40] as a self-reported measure of nicotine dependence and a lifetime history of cigarette smoking (the age at which they began smoking and the number of years they had smoked) was collected. Nicotine dependence was estimated by the HSI, which is based on two items extracted from the FTND: the number of cigarettes smoked per day and the time to the first cigarette of the day. A cut-off score of HSI $\geq 4$ was used to categorize individuals as highly dependent on nicotine [41].

\section{Genotyping}

Buccal swabs were collected from all participants and DNA was extracted with a DNA extraction kit (EPICENTRE ${ }^{\oplus}$ Biotechnologies, Madison, WI). The SLC6A3 VNTR polymorphisms were amplified by PCR [33] and resolved on $1.5 \%$ agarose gels using positive controls obtained by direct DNA sequencing. To genotype the TaqIA polymorphism, the amplicons were digested with TaqI [4] and resolved on $2 \%$ agarose gels. The genotyping of CYP2A6*4 was performed by the PCR-RFLP method, using digestion with Eco81I [45].

\section{Statistical analyses}

The genotypes of the polymorphisms were classified by the homozygosity of the major alleles as follows. SLC6A3 VNTR: $10 \mathrm{r} / 10 \mathrm{r}$ versus $10 \mathrm{r} /{ }^{*}$ or $* *$, where * refers to alleles with fewer than 10 repeats; TaqIA: A2/A2 versus A1/A2 or A1/A1; CYP2A6"4: "1/"1 versus "1/*4 or "4/"4. The VNTR, TaqIA, and CYP2A6"4 polymorphisms were tested for HWE in current smokers, former smokers, and the whole cohort.

The effect of the genetic polymorphisms on smoking cessation and the genotype frequency among the current and former smokers, and nicotine dependence estimated by the HSI score among current smokers, were examined. These analyses were conducted for both the whole cohort and male subjects only, because female participants accounted for only $8.3 \%$ of the cohort. Chi-squared analyses with the Yates correction were conducted to examine the association of genotype with smoking status and nicotine dependence. $P<0.01$ and a $95 \%$ confidence interval (CI) that did not include a value of 1.0 were considered statistically significant. The associations were further expressed as odds ratios (OR) with a 95\% CI.

We investigated the degree of nicotine dependence (the HSI score) among the current smokers generated by polymorphism-polymorphism interactions and the smoking histories of participants by two approaches using regression analysis. First, regression analyses were performed based on a method of forward-stepwise selection, by fixing the genetic polymorphism determined to be statistically significant by chi-squared analyses. Second, we performed forward-stepwise analyses using the twovariable combination of the age at which smoking began and the duration of smoking to determine the effect of smoking history on the relationship between nicotine dependence and the genetic polymorphism. The most appropriate model was selected based on Akaike's information criterion (AIC). $P<0.01$ was used as the cut-off for statistical significance.

\section{Competing interests}

All authors declare that they have no competing interests.

\section{Authors' contributions}

$\mathrm{MO}$ designed of the study, carried out the experiments, performed statistical analyses, and drafted the manuscript. YM, T, YK, and SK participated in the design of the study. YM and TT aided in the drafting of the manuscript. All authors read and approved the final manuscript.

\section{Acknowledgements}

We thank Prof. Osamu Oyama (Hokuriku University, Japan) and Yousuke Yamaguchi (Pharsas Inc., Japan) for insightful suggestions; Kana Numajiri, Yoshito Fukai, and Ayako Mizukami for assisting with DNA genotyping; and Yuto Fukushima, Yuki Kurosawa, and Yuki Miyagi for laboratory assistance. This research was supported by general grant to the Faculty of Pharmaceutical Sciences, Hokuriku University (H26-200480). The funding source had no involvement in the collection, analysis, or interpretation of the data, preparation of the manuscript, or the decision to submit the manuscript for publication.

Received: 18 July 2014 Accepted: 11 December 2014

Published online: 20 December 2014

\section{References}

1. Benowitz NL: Nicotine addiction. N Engl J Med 2010, 362:2295-2303.

2. Munafò MR, Johnstone EC: Genes and cigarette smoking. Addiction 2008, 103:893-904.

3. Neville MJ, Johnstone EC, Walton RT: Identification and characterization of ANKK1: a novel kinase gene closely linked to DRD2 on chromosome band 11q231. Hum Mutat 2004, 23:540-545.

4. Noble EP, St Jeor ST, Ritchie T, Syndulko K, St Jeor SC, Fitch RJ, Brunner RL, Sparkes RS: D2 dopamine receptor gene and cigarette smoking: a reward gene? Med Hypotheses 1994, 42:257-260.

5. Comings DE, Ferry L, Bradshaw-Robinson S, Burchette R, Chiu C, Muhleman $D$ : The dopamine $D 2$ receptor (DRD2) gene: a genetic risk factor in smoking. Pharmacogenetics 1996, 6:73-79.

6. Yoshida K, Hamajima N, Kozaki K, Saito H, Maeno K, Sugiura T, Ookuma K, Takahashi T: Association between the dopamine D2 receptor A2/A2 genotype and smoking behavior in the Japanese. Cancer Epidemiol Biomarkers Prev 2001, 10:403-405.

7. Hamajima N, Ito H, Matsuo K, Saito T, Tajima K, Ando M, Yoshida K, Takahashi T: Association between smoking habits and dopamine receptor D2 taql A A2 allele in Japanese males: a confirmatory study. J Epidemiol 2002, 12:297-304

8. Ohmoto M, Sakaishi K, Hama A, Morita A, Nomura M, Mitsumoto Y: Association between dopamine receptor 2 TaqIA polymorphisms and smoking behavior with an influence of ethnicity: a systematic review and meta-analysis update. Nicotine Tob Res 2013, 15:633-642.

9. Barr $\mathrm{CL}$, Kidd KK: Population frequencies of the $\mathrm{A} 1$ allele at the dopamine D2 receptor locus. Biol Psychiatry 1993, 15:204-209.

10. Lerman C, Caporaso NE, Audrain J, Main D, Bowman ED, Lockshin B, Boyd $N R$, Shields PG: Evidence suggesting the role of specific genetic factors in cigarette smoking. Health Psychol 1999, 18:14-20. 
11. Sabol SZ, Nelson ML, Fisher C, Gunzerath L, Brody CL, Hu S, Sirota LA, Marcus SE, Greenberg BD, Lucas FR 4th, Benjamin J, Murphy DL, Hamer DH: A genetic association for cigarette smoking behavior. Health Psychol 1999 18:7-13

12. Jorm AF, Henderson AS, Jacomb PA, Christensen H, Korten AE, Rodgers B, Tan X, Easteal S: Association of smoking and personality with a polymorphism of the dopamine transporter gene: results from a community survey. Am J Med Genet 2000, 96:331-334.

13. Vandenbergh DJ, Bennett CJ, Grant MD, Strasser AA, O'Connor R, Stauffer RL, Vogler GP, Kozlowski LT: Smoking status and the human dopamine transporter variable number of tandem repeats (VNTR) polymorphism: failure to replicate and finding that never-smokers may be different. Nicotine Tob Res 2002, 4:333-340.

14. Sieminska A, Buczkowski K, Jassem E, Niedoszytko M, Tkacz E: Influences of polymorphic variants of DRD2 and SLC6A3 genes, and their combinations on smoking in Polish population. BMC Med Genet 2009, 10:92.

15. Erblich J, Lerman C, Self DW, Diaz GA, Bovbjerg DH: Stress-induced cigarette craving: effects of the DRD2 Taql RFLP and SLC6A3 VNTR polymorphisms. Pharmacogenomics J 2004, 4:102-109.

16. Erblich J, Lerman C, Self DW, Diaz GA, Bovbjerg DH: Effects of dopamine D2 receptor (DRD2) and transporter (SLC6A3) polymorphisms on smoking cue-induced cigarette craving among African-American smokers. Mol Psychiatry 2005, 10:407-414.

17. Perkins KA, Lerman C, Grottenthaler A, Ciccocioppo MM, Milanak M, Conklin CA, Bergen AW, Benowitz NL: Dopamine and opioid gene variants are associated with increased smoking reward and reinforcement owing to negative mood. Behav Pharmacol 2008, 19:641-649.

18. Schmid B, Blomeyer D, Becker K, Treutlein J, Zimmermann US, Buchmann AF, Schmidt MH, Esser G, Banaschewski T, Rietschel M, Laucht M: The interaction between the dopamine transporter gene and age at onset in relation to tobacco and alcohol use among 19-year-olds. Addict Biol 2009, 14:489-499.

19. Oscarson M: Genetic polymorphisms in the cytochrome P450 2A6 (CYP2A6) gene: implications for interindividual differences in nicotine metabolism. Drug Metab Dispos 2001, 29:91-95.

20. Minematsu $N$, Nakamura $H$, Iwata $M$, Tateno $H$, Nakajima $T$, Takahashi $\mathrm{S}$, Fujishima S, Yamaguchi K: Association of CYP2A6 deletion polymorphism with smoking habit and development of pulmonary emphysema. Thorax 2003, 58:623-628

21. Kubota T, Nakajima-Taniguchi C, Fukuda T, Funamoto M, Maeda M, Tange E, Ueki R, Kawashima K, Hara H, Fujio Y, Azuma J: CYP2A6 polymorphisms are associated with nicotine dependence and influence withdrawal symptoms in smoking cessation. Pharmacogenomics J 2006, 6:115-119.

22. Batra A, Gelfort G, Bartels M, Smoltczyk H, Buchkremer G, Riess O, Schöls L: The dopamine $\mathrm{D} 2$ receptor (DRD2) gene-a genetic risk factor in heavy smoking? Addict Biol 2000, 5:429-436.

23. Bierut $L$, Rice JP, Edenberg HJ, Goate A, Foroud T, Cloninger CR, Begleiter $\mathrm{H}$, Conneally PM, Crowe RR, Hesselbrock V, Li TK, Nurnberger JI Jr, Porjesz B, Schuckit MA, Reich T: Family-based study of the association of the dopamine $\mathrm{D} 2$ receptor gene (DRD2) with habitual smoking. Am J Med Genet 2000, 90:299-302.

24. Johnstone EC, Yudkin PL, Hey K, Roberts SJ, Welch SJ, Murphy MF, Griffiths SE, Walton RT: Genetic variation in dopaminergic pathways and short-term effectiveness of the nicotine patch. Pharmacogenetics 2004, 14:83-90.

25. Morton LM, Wang SS, Bergen AW, Chatterjee N, Kvale P, Welch R, Yeager M, Hayes RB, Chanock SJ, Caporaso NE: DRD2 genetic variation in relation to smoking and obesity in the Prostate, Lung, Colorectal, and Ovarian Cancer Screening Trial. Pharmacogenet Genomics 2006, 16:901-910.

26. Connor JP, Young RM, Lawford BR, Saunders JB, Ritchie TL, Noble EP: Heavy nicotine and alcohol use in alcohol dependence is associated with D2 dopamine receptor (DRD2) polymorphism. Addict Behav 2007, 32:310-319.

27. Laucht M, Becker K, Frank J, Schmidt MH, Esser G, Treutlein J, Skowronek $\mathrm{MH}$, Schumann $\mathrm{G}$ : Genetic variation in dopamine pathways differentially associated with smoking progression in adolescence. J Am Acad Child Adolesc Psychiatry 2008, 47:673-681

28. Tan W, Chen GF, Xing DY, Song CY, Kadlubar FF, Lin DX: Frequency of CYP2A6 gene deletion and its relation to risk of lung and esophageal cancer in the Chinese population. Int J Cancer 2001, 95:96-101.

29. Loriot MA, Rebuissou S, Oscarson M, Cenée S, Miyamoto M, Ariyoshi N, Kamataki T, Hémon D, Beaune P, Stücker I: Genetic polymorphisms of cytochrome P450 2A6 in a case-control study on lung cancer in a French population. Pharmacogenetics 2001, 11:39-44.

30. Ando M, Hamajima N, Ariyoshi N, Kamataki T, Matsuo K, Ohno Y Association of CYP2A6 gene deletion with cigarette smoking status in Japanese adults. J Epidemiol 2003, 13:176-181

31. Fujieda M, Yamazaki H, Saito T, Kiyotani K, Gyamfi MA, Sakurai M, Dosaka-Akita $H$, Sawamura Y, Yokota J, Kunitoh H, Kamataki T: Evaluation of CYP2A6 genetic polymorphisms as determinants of smoking behavior and tobacco-related lung cancer risk in male Japanese smokers. Carcinogenesis 2004, 25:2451-2458.

32. Liu T, David SP, Tyndale RF, Wang H, Zhou Q, Ding P, He YH, Yu XQ, Chen W, Crump C, Wen XZ, Chen WQ: Associations of CYP2A6 genotype with smoking behaviors in southern China. Addiction 2011, 106:985-994.

33. Sano A, Kondoh K, Kakimoto Y, Kondo I: A 40-nucleotide repeat polymorphism in the human dopamine transporter gene. Hum Genet 1993, 91:405-406.

34. Nakatome M, Honda K, Islam MN, Terada M, Yamazaki M, Kuroki H, Ogura Y, Bai H, Wakasugi C: Amplification of DAT1 (human dopamine transporter gene) 3' variable region in the Japanese population. Hum Hered 1995, 45:262-265

35. Heatherton TF, Kozlowski LT, Frecker RC, Rickert W, Robinson J: Measuring the heaviness of smoking: using self-reported time to the first cigarette of the day and number of cigarettes smoked per day. Br J Addict 1989, 84:791-799.

36. van Dyck CH, Malison RT, Jacobsen LK, Seibyl JP, Staley JK, Laruelle M, Baldwin RM, Innis RB, Gelernter J: Increased dopamine transporter availability associated with the 9-repeat allele of the SLC6A3 gene. J Nucl Med 2005, 46:745-751.

37. Michelhaugh SK, Fiskerstrand C, Lovejoy E, Bannon MJ, Quinn JP: The dopamine transporter gene (SLC6A3) variable number of tandem repeats domain enhances transcription in dopamine neurons. J Neurochem 2001, 79:1033-1038

38. Stapleton JA, Sutherland G, O'Gara C: Association between dopamine transporter genotypes and smoking cessation: a meta-analysis. Addict Biol 2007, 12:221-226.

39. O'Gara C, Stapleton J, Sutherland G, Guindalini C, Neale B, Breen G, Ball D: Dopamine transporter polymorphisms are associated with short-term response to smoking cessation treatment. Pharmacogenet Genomics 2007, 17:61-67.

40. Heatherton TF, Kozlowski LT, Frecker RC, Fagerström KO: The fagerström test for nicotine dependence: a revision of the fagerström tolerance questionnaire. Br J Addict 1991, 86:1119-1127.

41. de Leon J, Diaz FJ, Becoña E, Gurpegui M, Jurado D, Gonzalez-Pinto A: Exploring brief measures of nicotine dependence for epidemiological surveys. Addict Behav 2003, 28:1481-1486.

42. Kozlowski LT, Porter CQ, Orleans CT, Pope MA, Heatherton T: Predicting smoking cessation with self-reported measures of nicotine dependence: FTQ, FTND, and HSI. Drug Alcohol Depend 1994, 34:211-216.

43. Dani JA, Heinemann S: Molecular and cellular aspects of nicotine abuse. Neuron 1996, 16:905-908.

44. Munafò MR, Timpson NJ, David SP, Ebrahim S, Lawlor DA: Association of the DRD2 gene Taq1A polymorphism and smoking behavior: a meta-analysis and new data. Nicotine Tob Res 2009, 11:64-76.

45. Ariyoshi N, Takahashi Y, Miyamoto M, Umetsu Y, Daigo S, Tateishi T, Kobayashi S, Mizorogi Y, Loriot MA, Stücker I, Beaune P, Kinoshita M, Kamataki T: Structural characterization of a new variant of the CYP2A6 gene (CYP2A6*1B) apparently diagnosed as heterozygotes of CYP2A6*1A and CYP2A6*4C. Pharmacogenetics 2000, 10:687-693.

\section{Submit your next manuscript to BioMed Central and take full advantage of:}

- Convenient online submission

- Thorough peer review

- No space constraints or color figure charges

- Immediate publication on acceptance

- Inclusion in PubMed, CAS, Scopus and Google Scholar

- Research which is freely available for redistribution 